\title{
A COMPREHENSIVE STUDY ON GELLED PROPELLANTS
}

\author{
Rupesh Aggarwal ${ }^{1}$, Ishan K. Patel ${ }^{2}$, P.B. Sharma ${ }^{3}$, Thirumalvalavan ${ }^{4}$ \\ ${ }^{1}$ Teaching Assistant, Department of Aerospace, Amity University Haryana, India \\ ${ }^{2} U G$ Student, Department of Aerospace, Amity University Haryana, India \\ .${ }^{3}$ PhD (Birmingham) FIE, FAeroS, FWAPS, Vice Chancellor, Amity University Haryana, India \\ ${ }^{4} U G$ Student, Department of Aerospace, Amity University Haryana, India
}

\begin{abstract}
The present study focuses on the review of a different kind of propellant, known as gel propellant for the future use in rockets \& missiles. Work includes its physical aspects, classification, atomization, combustion characteristics, preparation, gellants, its advantages over solid and liquid based propellant, green propellant based on it and its applications.
\end{abstract}

KeyWords:Gel Propellants, Gellant, Gelling Agents, Green propellants, Gel Atomization, Rocket propellant.

\section{INTRODUCTION}

The basic difficulty with rocket fuels is that liquid fuels, utilized in rockets like the Shuttle boosters, can drip. Solid fuels, such as Ammonium Perchlorate Composite Propellant (APCP), contrariwise don't leak, but they withal have much lower specific impulse, are harder to throttle, and necessitate distinct high pressure combustion chambers. Furthermore, Solid propelled rocket engines require intricate design and manufacturing to empower variable thrust. Distinct to liquid propellant, where propellant flow might controlled to throttling of thrust. However, liquid propellant is much more arduous to store, handle and convey.

With increasing demand of high-performance and improvements in safety factors related to rocket propellants, innovative kind of propellant is introduced - Gelled Propellant. Gels can be defined as the fluids whose rheological characteristics are reformed by the additament of suitable gelling agents (gellants) and so they resembles to both liquids and solid in many aspects.[1]

Gel-predicated rocket propellant could provide the best unification - allowing modulation of thrust to maximize weapon durability and performance, while offering more shelf life and greater operational ability. The benefits of this propulsion technology are the variability of thrust for mission acclimated multiple thrust profiles, the very high degree of callousness (no reaction at expeditious and slow cook-off), and low smoke and low signature. Furthermore, it is an environmentally amicable propellant (green propellant) and facile handling regarding the logistics chain.

\section{GEL PROPELLANT - PHYSICAL ASPECTS}

Behavior of Gel propellants can be assumed by studying its flow and deformation properties under static as well as dynamic forces applied. The study is called Rheology. It applies to substances such as Non-Newtonian substances. Florry classified gel into four kinds [2]:
[1]. Regimented laminar structures, together with gel mesophases;

[2]. Entirely disordered covalent polymeric links;

[3]. Polymericwebsmadeover physical accretion, primarily tangled;

[4]. Microscopically disorderlyconfigurations.

Wide variety of gel propellants employed in rocket propulsion systems are of type 3. Furthermore, there are three phases of polymerization of gel propellants: (I) polymerization of singular elements to form bigger elements, (II) accumulation to form bigger molecules, (III) creation of chainswhichlengthen throughout the liquescent, and condensing into gel.

\subsection{Governing Equations}

Some Characteristics like burning,flow characteristicsand atomization are governed by few constitutive equations signifying fundamental relationship between force and distortion in materials, predominantly liquids.[3] A schematic classification on the basis of rheological properties is presented in Fig.1.

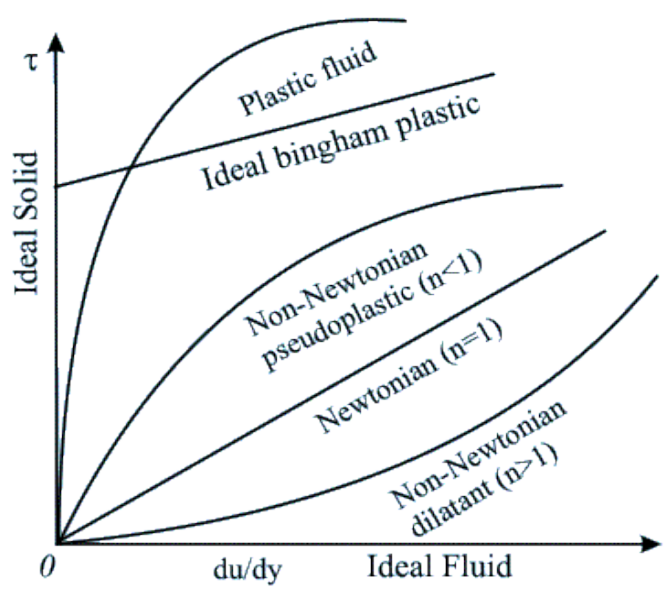

Fig -1: Shear stress and deformation rate relationship of different fluids 
A general relationship between stress tensor, $\tau$ and rate of deformation tensor, $\mathrm{T}$ for a viscous fluid is defined as:

$\tau=\eta \cdot T$

Above mentioned equation can be used in the form of wellknown Power Law. For a steady shear the power law turn out to be:

$\tau_{12}=\tau_{21}=\mathrm{K} \dot{\gamma}^{n}$

This law is used comprehensively in method of polymerprocessing. Non-Newtonian fluids show shear thinning demeanor, i.e., $\mathrm{n} \in(0,1)$, but some, dilatant liquids, concretely concentrated suspensions, express shear thickening comportment, i.e., $\mathrm{n} \in(1, \mathrm{c})$. Other considerable characteristics are time-dependent viz. thixotropy and rheopecticity. Thixotropicity is the property which indicates alleviation in viscosity under unvarying shear forces, whilst rheopecticity is reverse of thixotropicity, i.e., elevation in viscosity with unvarying shear forces.

\subsection{Temperature Effects}

Temperature variations suggests notable variations in rheologicalpropertiesof gels. This is noted that gels have negative density gradient with respect to temperature variations. Gupta et al as well asRahimi\&Natan.[4][5] studied temperature-density relationship for gels. Moreover, empirical study over water gels suggests considerable lowering in consistency index and value of $n$ with rise in temperature.

\section{FLOW PROPERTIES}

All throughout the victualing process, gel propellants pass through network of supply tubes and finally sprayed into the combustion chamber with help of specially designed atomizers. Gels are liquefied while passing through the injectors due to sudden increase in shear forces within a short period of time. This shows the shear-thinning property of the gel propellants. Additionally time-dependent property - thixotropy should be taken into account while considering longer duration flows.

\subsection{Pseudo Plastic Flows:}

It is known that by increasing shear rate, viscosity of gels can be lowered up to theextent where it can start to liquefy. This is achieved as a result of application of a converging nozzle to inject high density gels in the form of atomized jet. Whilst flowing through the converging section of the nozzle, gel speeds up thereby increasing shear forces, which in turn decrease the viscosity. Mansour and Chigier betoken that to associate atomization characteristics of gels with the dynamic viscosity averaged over mass, intricate nonNewtonian flow field has to be solved [6]. Furthermore, Rahimi and Natan[7] solved mathematical relations between various properties of pseudo plastic gel propellant governed by power law model.

\subsection{Thixotropic Flows:}

It is the time-dependent shear thinning property. Certain gels or fluids will flow over time under applied stress. This effect is immaterial for gel propellants. Anyhow the diameter to length ratio is an important design parameter.

\section{CATEgORIZATION}

Gel propellants are categorize into three, based on their rheological properties [8]:

\subsection{Pseudoplastic, Shear Thinning, Low-Yield:}

Follows models like power law, cross, Carreau-Yasuda and Herschel-Bulkley. Thixotropy and temperature sensitivity are comparatively lower. Inorganic fuels and water gels such as carbopols fall under this category.

\subsection{Viscoelastic Gel:}

These type gels follows Bogers constitutive model. Organic fuels falls under this category of gel propellant.

\subsection{Yield thixotropic:}

Follows models viz. Bingham, Casson, Cross and CarreauYasuda. They have relatively higher thixotropy. Many organic fuels and other substances like $\mathrm{H}_{2} \mathrm{O}_{2}$ and corresponding acids falls under this category.

\section{GELLING AGENTS/ GELLANTS}

Gelling agents render congruous mechanical properties to the primary liquescent without compromising any minimal effect on energy output taken from the propellant. Much less research work has been stimulated that accedes with methodological formulation of gel propellants [9][10].

Type of gellant employed and its contents together determine the rheological properties of the gel propellant. Escalation in gel content results in a rise in the shear viscosity. Moreover, to obtain desired output, various gellants can be agglomerated together to compose a cumulatedgellant[11].

The different gelling agents for various propellants are listed in Table 1

Table -1: Various Gel Propellants \&Gellants

\begin{tabular}{|c|c|c|c|c|}
\hline \multirow{2}{*}{$\begin{array}{l}\mathbf{S} \\
\mathbf{N} \\
\mathbf{o .}\end{array}$} & \multirow[b]{2}{*}{ Gellants } & \multicolumn{3}{|c|}{ Employed In } \\
\hline & & Fuels & $\begin{array}{l}\text { Oxid } \\
\text { izers }\end{array}$ & $\begin{array}{l}\text { Monopropel } \\
\text { lants }\end{array}$ \\
\hline 1 & $\mathrm{SiO}_{2}$ & $\begin{array}{l}\text { RP-1 } \\
\text { UDMH }\end{array}$ & $\begin{array}{l}\text { IRFN } \\
\mathrm{A}, \\
\mathrm{ClF}_{5}, \\
\mathrm{H}_{2} \mathrm{O}_{2}\end{array}$ & $\begin{array}{l}\mathrm{N}_{2} \mathrm{O}_{4} \\
\text { TEGDN/TM } \\
\text { ETN/ } \mathrm{H}_{2} \mathrm{O}_{2} \\
\mathrm{HN} / \mathrm{AN}\end{array}$ \\
\hline 2 & $\begin{array}{l}\text { Colloidal } \\
\text { Silica }\end{array}$ & Hydrazine & $\begin{array}{l}\text { RFN } \\
\text { A }\end{array}$ & $\begin{array}{l}\mathrm{N}_{2} \mathrm{H}_{4} \\
\mathrm{RFNA} \\
\mathrm{N}_{2} \mathrm{H}_{4}\end{array}$ \\
\hline 3 & Silica gel & --- & --- & $\begin{array}{l}\text { Sodium } \\
\text { Perchlorate / } \\
\text { HAP }\end{array}$ \\
\hline
\end{tabular}




\begin{tabular}{|c|c|c|c|c|}
\hline 4 & $\begin{array}{l}\text { Cellulose \& } \\
\text { its derivatives }\end{array}$ & $\begin{array}{l}\text { UDMH, } \\
\text { MMH, } \\
\mathrm{N}_{2} \mathrm{H}_{4} \\
\text { UDMH } \\
\text { JP-10 }\end{array}$ & --- & $\begin{array}{l}\text { Ethyl Nitrate } \\
\text { /Propyl Ether }\end{array}$ \\
\hline 5 & $\begin{array}{l}\text { Sodium } \\
\text { Silicate }\end{array}$ & --- & $\begin{array}{l}\text { RFN } \\
\text { A }\end{array}$ & --- \\
\hline 6 & $\begin{array}{l}\text { Clay } \\
\text { compounds }\end{array}$ & $\begin{array}{l}\text { UDMH, } \\
\text { HEL, } \\
\text { MMH, } \\
\text { Kerosene }\end{array}$ & --- & --- \\
\hline 7 & $\mathrm{P}_{4} \mathrm{O}_{10}$ & --- & $\begin{array}{l}\text { IRFN } \\
\text { A }\end{array}$ & --- \\
\hline 8 & carbon & --- & --- & HIRFNA \\
\hline 9 & $\begin{array}{l}\text { Aluminium } \\
\text { Oxide }\end{array}$ & --- & --- & LOX \\
\hline 10 & BTMSE & $\mathrm{H}_{2}$ & -- & --- \\
\hline 11 & $\begin{array}{l}\text { Polyacrylamid } \\
\mathrm{e}\end{array}$ & --- & --- & Hydrazine \\
\hline 12 & $\begin{array}{l}\text { HEC } \\
\text { (Hydroxyleth } \\
\text { ylcellulosw) }\end{array}$ & $\begin{array}{l}\text { UDMH, } \\
\mathrm{MMH}, \\
\mathrm{N}_{2} \mathrm{H}_{4} / \mathrm{MM} \\
\mathrm{H} / \mathrm{UDMH}, \\
\mathrm{MHF}\end{array}$ & --- & $\begin{array}{l}\text { Ethyl nitrate } \\
\text { / Propyl } \\
\text { nitrate }\end{array}$ \\
\hline 13 & $\begin{array}{l}\begin{array}{l}\text { Propylene } \\
\text { glycol }\end{array} \\
\end{array}$ & Kerosene & --- & --- \\
\hline 14 & Kelzan & $\begin{array}{l}\text { MHF, } \\
\text { Hydrazine }\end{array}$ & --- & --- \\
\hline 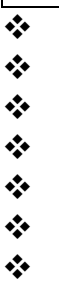 & $\begin{array}{l}\text { HAP - Hydroxyl } \\
\text { HIRFNA - HNO } \\
\text { IRFNA - Inhibite } \\
\text { RFNA - Red Fun } \\
\text { MHF - Mixed Hy } \\
\text { TEGDN - Triethy } \\
\text { TMETN - Trime }\end{array}$ & $\begin{array}{l}\text { ammonium per } \\
, \mathrm{N}_{2} \mathrm{O}_{4}, \mathrm{HF}, \mathrm{H}_{2} \\
\mathrm{~d} \mathrm{Ref} \mathrm{Fuming} \\
\text { ing Nitric Aci } \\
\text { drazine Fuels } \\
\text { lene Glycol D } \\
\text { hyloethaneTin }\end{array}$ & $\begin{array}{l}\text { rchlorate } \\
{ }_{2} \\
\text { Nitric A } \\
d\end{array}$ & \\
\hline
\end{tabular}

\section{ATOMIZATION OF GEL PROPELLANTS}

Atomization is essential to get higher combustion efficiency. It is known that higher viscosities produce granular jet. Besides, gels have relatively larger mag of viscosity. Thus, atomization of gels is remarkably different from that of Newtonian fluids such as kerosene or water.

The main problem concerning atomization in ordinary orifice injectors is the high pressure generation within smaller angle of jet. This problem can be solved by utilizing triple air-blast atomizer, wherein the jet of gel propellant is injected, either parallel to the direction of moving gas or at some angle as shown in Figure 2. This method substantiated to entail lower pressure for the same results. In this design, nitrogen is usedas atomizing gas.

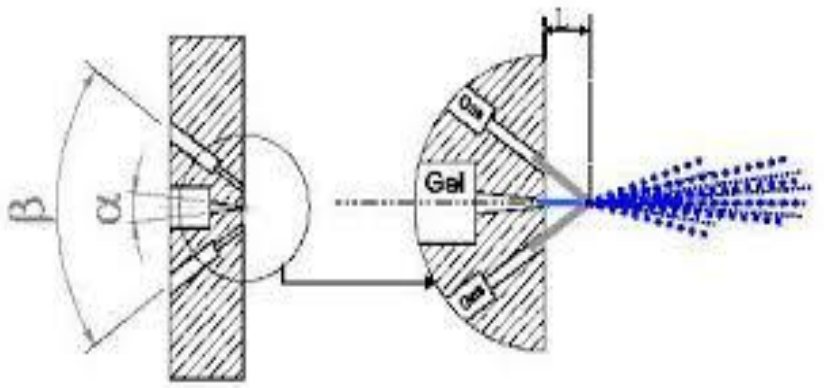

Fig -2: A Triplet Air-blast Atomizer

Dexterstudied effect of elongation viscosity on jet of polymer solutions.[12] He stated that the mag of shear viscosities is less than that of elongation viscosity, so shear viscosity effects are of trivial significance.

There are only few research works present till this date stimulating gel propellants. A study has been conducted by Green et al, to compare the features of gelled and non-gelled propellants. Experimental photographs of the jet configurations suggests that gelled propellants are unable to produce adequate jet when compared to the non-gelled propellant. The reason is higher viscosities of gel propellants, which prevent atomizers from producing fine granules of propellant [13]. Furthermore, the authors betokened that with change in mass flow rate of propellant through the atomizer, there was significant variation in atomization characteristics of the gel. This was contrary to the initial studies over atomization Newtonian and nonNewtonian fluids. The answer to this misapprehension could be that there might be expansion of jet-profile due to increase exit plane speed of atomized gel [14].

\section{COMBUSTION CHARATERISTICS}

\subsection{Metallized Gel Propellants}

This set of gelled propellant is substantially studied for the last 30 years. Foregoing study over metallized gel propellant revealed that the solid aggregates were persisted even after the vaporization of the liquescent [15]. They were discerned to be hollow with a permeable configuration.

\subsection{Non-Metalized Gel Propellants}

This is necessary to distinguish the combustion characteristics of gel propellants from that of the liquid droplet combustion process. In spite, study encompassing various phenomena of combustion of gel propellant is very diminutive.

Besides, liquid droplet combustion processes have been thoroughly studied. For instance, Eldridge and Ferry betokened that increment in amount of gelatin raises melting point of gelatin induced gels. However, the effect of per cent weight of gallant and its type on the heat of vaporization of gels is unknown.[16]

Galecki, Palazewski.and Zakany studied the combustion characteristics of $\mathrm{Al} / \mathrm{HC}$ gels burnt in rocket combustion 
chamber in the vicinity of gaseous oxygen [17][18]. They inferred that gelled propellants show relatively lower combustion efficiency with respect to corresponding nongelled propellant.

\section{GEL BASED GREEN PROPELLANT}

Gel propellants render comparatively lower smoke and lower signature in comparison of corresponding liquid and solid propellants. Moreover most distinguished among all gel variants that can be considered environment friendly is high test hydrogen peroxide (HPE)/Boron carbide based $\mathrm{SiO} 2$ induced gel propellant. Another potential compound which can be categorized as "green" gel propellant is hydroxyl ammonium nitrate (HAN) and its derivatives. To this day, researchers are finding new ways to gellatize the "green" substitutes of conventional liquid monopropellants.

\section{APPLICATION}

\subsection{Gelled Propellant Based Rocket Motor}

A gelled propellant rocket motor (GRM) cumulates the advantages of a solid rocket motor (SRM) - facile handling and extended shelf life with those of a liquid rocket motor (LRM) - thrust modulation switch on/off capability and the potential for extended operation periods.[19] It performs better than both solid and liquid rockets in terms of: Safety and Callousness in instance of accidents, since the propellants are not explosives, there is no leak in case of drip or perforation of the tanks, and gels have much lesser vapor pressure than liquid fuels and hence a considerably lower evaporation rate in case of eradication of the tank.

Functioning of the GRM is based on the fact that the gelled propellant is solid in the tank, while liquefied upon injection into the combustion chamber due to high shear rates induced by high injection pressure generated either by SPGG or a piston drive. The atomization and combustion process is similar to that of an LRM burning storable propellants.

\section{ADVANTAGES OVER SOLID \& LIQUID}

Table -2: Comparison

\begin{tabular}{|c|c|c|}
\hline \multicolumn{2}{|c|}{ Aspects/factors } & \multirow{2}{*}{$\begin{array}{l}\text { Explanation } \\
\text { Leakage rate is less as } \\
\text { compared to liquids as gel } \\
\text { surface gets hardens in gaseous } \\
\text { environment. Also its } \\
\text { rheological nature will prevent } \\
\text { it from flow. }\end{array}$} \\
\hline & Leaks \& Spill & \\
\hline$\frac{n}{0}$ & $\begin{array}{l}\text { Sensitivity to } \\
\text { impact, friction } \\
\text { and electrostatic } \\
\text { discharge }\end{array}$ & $\begin{array}{l}\text { Gels are insensitive like liquids } \\
\text { in comparison with solids where } \\
\text { explosion can takes place }\end{array}$ \\
\hline 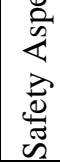 & $\begin{array}{l}\text { Accidental } \\
\text { Ignition }\end{array}$ & $\begin{array}{l}\text { In gel same as of liquid, } \\
\text { combustion is controllable } \\
\text { whereas in solids, motor } \\
\text { ignition can lead to a disaster. }\end{array}$ \\
\hline
\end{tabular}

\begin{tabular}{|c|c|c|}
\hline & Cracks & $\begin{array}{l}\text { Gel, similar to liquid, fed } \\
\text { directly to combustion chamber } \\
\text { which cause no effect of crack } \\
\text { on gel structure whereas in } \\
\text { solid, crack can lead to an } \\
\text { uncontrollable combustion and } \\
\text { at last explosion. }\end{array}$ \\
\hline \multirow{3}{*}{ 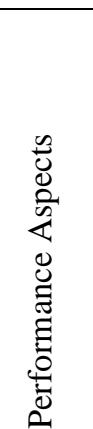 } & Specific Impulse & $\begin{array}{l}\text { Gel have same impulse as of } \\
\text { liquids, and can increase if } \\
\text { metal particles are introduced. }\end{array}$ \\
\hline & Impulse Density & $\begin{array}{l}\text { Metallized gel have better } \\
\text { density impulse then liquids. }\end{array}$ \\
\hline & $\begin{array}{l}\text { Energy } \\
\text { Management }\end{array}$ & Gel have same as of Liquids \\
\hline \multirow[b]{2}{*}{ 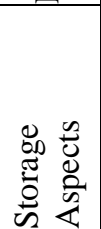 } & Stability & $\begin{array}{l}\text { Gel have more than } 10 \text { years of } \\
\text { storage capability }\end{array}$ \\
\hline & Packing & $\begin{array}{l}\text { Flexible packing, same as of } \\
\text { liquids }\end{array}$ \\
\hline
\end{tabular}

\section{CONCLUSIONS}

Gel propellants have many advantages over Solid and Liquid propellants, however there are certain shortcoming of this system viz. There is requirement for a powerful tank pressurization system and a tank design that tolerates high internal pressure. Moreover, from the standpoint of mechanism of atomizers and delivery tube system, extensive study is required to be detained. Another problem with gelled propellant is its lower combustion efficiency due to comparatively higher density. Though utilization of certain additives might increase burning rates by incrementing vapor pressures of the gel up to a considerate extent.

\section{REFERENCES}

[1]. Brinker, C.J. and Scherer, G.W., "Sol-Gel Science," Academic Press, Inc., Boston, 1990.

[2]. Flory, P.J., "Introductory lecture," in "Gels and Gelling Processes," Faraday Discussions of theChemical Society, Vol. 57, 1974, pp. 7-18.

[3]. Kukushkin, V. and Ivanchenko, A., "The pasty Propellant Rocket Engines Development," AIAA paper93-1754, June 1993.

[4]. Gupta, B.L., Varma, M. and Munjal, N. L., "Rheological Studies on Virgin and MetallizedUnsymmetrical Dimethyl Hydrazine," Propellants, Explosives, Pyrotechnics, Vol. 11, No. 2, 1986, pp.45 52.

[5]. Rahimi, S. and Natan, B., "The Flow of Gel Fuels in Tapered Injectors," J. of Propulsion and Power, Vol. 16, No. 3, 2000, pp. 458-471.

[6]. Mansour A. and Chigier N., "Air-blast atomization of non-Newtonian liquids," J. of Non-Newtonian Fluid Mechanics, Vol. 58, 1995, pp. 161-194.

[7]. Rahimi, S. and Natan, B., "Numerical Solution of the Flow of Power Law Gel Propellants in 
ConvergingInjectors," accepted for publication in Propellants, Explosives, Pyrotechnics, April 2000.

[8]. Rahimi, S. and Natan, B., "The status of gel propellants in year 2000", combustion of energetic materials, 2001, pp.9

[9]. Varghese, T.L., Gaindhar, S.C., John D., Josekutty J., Muthiah, Rm., Rao, S.S., Ninan, K.N. andKrishnamurthy, V.N., "Developmental Studies on metallized UDMH and Kerosene Gels," DefenseScience Journal, Vol. 45, No. 1, January 1995, pp. 25-30.

[10]. Varma, .M., Gupta, B.L., Pandey, M., "Formulation \& Storage Studies on Hydrazine-Based GelledPropellants," Defense Science Journal, Vol. 46, No. 5, 1996, pp. 435-442.

[11]. Rahimi, S. and Natan, B., "Atomization Characteristics of Gel Fuels," AIAA paper 98-3830, July 1998.

[12]. Dexter, R.W., "Measurement of extensional viscosity of polymer solutions and its effects on atomization from a spray nozzle," J. of Atomization and Sprays, Vol. 6, 1996, pp. 167-191.

[13]. Green, M.J., Rapp, D.C. and Roncace, J., "Flow Visualization of a Rocket Injector Spray Using GelledPropellant Simulants," AIAA paper 91-2198, June 1991.

[14]. Rahimi, S., "The Injection Process of Gel Fuels", M.Sc. Thesis, Technion - Israel Institute of Technology, Dec.1999

[15]. Szekeley, G.A. Jr. and Faeth, G.M., "Combustion Properties of Carbon Slurry Drops," AIAA J., Vol. 20, 1982, pp. 422-429.

[16]. Eldridge, J.E. and Ferry, J.D., "Studies of the CrossLinking Process in Gelatin Gels. III. Dependence of Melting Point on Concentration and Molecular Weight," J. of Physical Chemistry, Vol. 58, 1954, pp. 992-994.

[17]. Galecki, D.L., "Ignition and Combustion of Metallized Propellants," AIAA paper 89-2883, July 1989.

[18]. Palaszewski, B. and Zakany, J.S., "Metallized Gelled Propellants: Oxygen / RP-1 / Aluminum Rocket Heat Transfer and Combustion Measurements," AIAA paper 96-2622, July 1996.

[19]. Natan B. and Rahimi S., "The Status of Gel Propellants in Year 2000" in: Combustion ofEnergetic Materials, pp. 172-194 (eds.: K.K. Kuo and L.T. DeLuca), Begell House, USA, 2002. 